\title{
THE MYTH OF CHINA'S OPEN MARKET REFORMS AND THE WORLD TRADE ORGANIZATION
}

\author{
DANIEL C.K. CHOW*
}

\begin{abstract}
In 2018, the Trump Administration claimed for the first time that the United States erred in supporting China's accession to the World Trade Organization because China has failed to fulfill its commitments to dismantle its state-led economy and adopt openmarket oriented reforms. Instead, China has maintained a mercantilist state-led economy in which China provides preferential treatment to its state-owned enterprises and supports their exports while it discriminates against U.S. companies in China and creates barriers to U.S. imports. Frustrated with being unable to effect change through dialogue, the United States is now using punitive trade sanctions against China in disregard of the WTO. China has retaliated in kind, igniting a potential global trade war.

A review of the background of China's accession to the WTO indicates, however, that China never made any commitments to dismantle the state sector of its economy and is not otherwise legally bound to do so under the WTO. The claim that China agreed to adopt open markets is a myth created by President Bill Clinton due to wishful thinking or political expediency when he sought congressional support for China's accession to the WTO in 2001. Clinton argued that China's WTO entry would lead to the adoption of economic freedoms that in turn would lead to political freedoms and greater protection for human rights. Clinton even dangled the

\footnotetext{
* Frank E. and Virginia H. Bazler Chair in Business Law, Ohio State University Michael E. Moritz College of Law. B.A., J.D., Yale University. The author lived and worked in China as in-house counsel at a multinational company. In the course of this employment, the author was able to meet regularly with Chinese government officials and discuss many matters pertaining to the U.S.-China relationship.
} 
possibility China could shed the shackles of communism and embrace democracy. In response to Clinton's grandiose vision, China remained cautious and made no extravagant promises. China promised only to adopt a hybrid system in which some free markets would operate within an overall state-led economy. Rather than dismantling its state-led economy after its WTO accession, China has incessantly strengthened it. Tightening the state's grip over the economy serves important goals of the Communist Party, including further entrenching its power, whereas loosening its grip would be tantamount to relinquishing power, a prospect that the Party will never accept. This Article argues that the United States must finally reject the Clinton myth and accept that China has no intention of dismantling its state-led economy. Only with this sober realization can the United States deal effectively in the future with China in the WTO, in bilateral trade negotiations outside of the WTO, and beyond. 


\section{TABLE OF CONTENTS}

I. Introduction 942

II. China's Accession to the WTO and the Myth of Open

Market Reforms 948

A. China's State-Led Economy and the WTO................ 948

B. China's Accession to the WTO and Its Obligation to Implement Market Reforms 953

1. China, the GATT, and Most Favored Nation Tariffs ................................................................. 953

2. Clinton's Vision of China and the WTO ......... 957

3. China's Views of Needed Reforms for the WTO ............................................................ 960

C. The WTO and Open Market-Oriented Policies.......... 962

III. The Communist Party and the State-Led Economy .... 965

A. China's SOEs in the New Millennium...................... 965

B. Party Control of the Economy through the State Sector

IV. Conclusion....................................................................... 973 


\section{INTRODUCTION}

Although the United States has long been critical of China's compliance with its obligations under the World Trade Organization (WTO), the Trump Administration broke new ground in 2018 by stating that "the United States erred in supporting China's entry into the WTO on terms that have proven ineffective in securing China's embrace of an open, market-oriented trade regime." 1 The claim that the United States mistakenly supported China's WTO membership goes beyond any criticism in previous U.S. administrations, which had always viewed China's membership in the WTO, with all of its shortcomings, as an overall benefit to the multilateral trading system. ${ }^{2}$ The Trump Administration's claim

1 Office of the U.S. Trade Representative, 2017 Report to Congress on CHINA'S WTO COMPLIANCE 2 (Jan. https:/ / ustr.gov/sites/default/files/files/Press/Reports/China\%202017\%20WT O\%20Report.pdf [https:/ / perma.cc/5ND7-NS74] [hereinafter 2017 USTR REPORT].

2 The pessimistic and critical tone of the 2017 USTR Report stands in stark contrast to annual USTR reports submitted during prior U.S. administrations on China's WTO compliance. These reports were markedly more optimistic and enthusiastic about China's membership in the WTO. For example, in its 2015 Report, submitted during the Obama Administration, the USTR referred to the "tremendous potential presented by China's WTO membership, including the breadth and depth of trade and investment-and prosperity-possible in a thriving, balanced global trading system." See OfFICE OF THE U.S. TRADE REPRESENTATIVE, 2015 REPORT TO CONGRESS ON CHINA'S WTO COMPLIANCE 4 (Dec. 2015), https://ustr.gov/sites/default/files/2015-Report-to-Congress-ChinaWTO-Compliance.pdf [https://perma.cc/7T57-KHTB]. In its 2010 Report, submitted during the Bush Administration, the USTR stated: "Despite the many challenges that remain, China's WTO membership has continued to provide substantial ongoing benefits to the United States. Each year since China joined the WTO, ... U.S.-China trade has expanded dramatically, providing numerous and substantial opportunities for U.S. businesses, workers, farmers and service suppliers and a wealth of affordable goods for U.S. consumers." See OFFICE OF THE U.S. TRADE REPRESENTATIVE, 2010 RePORT TO CONGRESS ON CHINA'S WTO COMPLIANCE 3 (Dec. 2010), https://ustr.gov/sites/default/files/uploads/ gsp/speeches/reports/2010/2010\%20Report $\% 20$ to \%20Congress $\% 20$ -

$\% 20$ Dec $\% 2023 \% 20$ Final.pdf [https://perma.cc/BX9C-NX7X]. In its first report on China's compliance with the WTO submitted during the Clinton Administration, the USTR stated: "Overall, during the first year of its WTO membership, China made significant progress in implementing its WTO commitments, although much is left to do.... Despite the compliance problems that arose over the course of the past year, most private sector representatives remain enthusiastic about the actual and potential benefits for U.S. industry from China's WTO membership." See OfFice of the U.S. TRADE REPRESENTATIVE, 2002 REPORT TO CONGRESS ON CHINA'S WTO COMPLIANCE 3, 5 (Dec. 2002), https://www.google.com/ url?sa $=\mathrm{t} \& \mathrm{rct}=\mathrm{j} \& \mathrm{q}=\& \mathrm{esrc}=\mathrm{s} \&$ source $=$ web\&cd $=1 \& \mathrm{cad}=\mathrm{rja} \& u a c t=8 \& \mathrm{ved}=2 \mathrm{ahUKEw}$ 
indicates a new level of U.S. dissatisfaction with China's WTO compliance and foreshadows new, more extreme measures in response. ${ }^{3}$

The crux of the Trump Administration's complaint is that China has broken its promises to implement economic reforms that would eventually dismantle China's state-led, mercantilist economy, including the economy's dominance by powerful state-owned enterprises (SOEs), business corporations that are administrative units of the state. ${ }^{4}$ Under the U.S. view, China made legal commitments as part of its entry into the WTO under its Protocol of Accession, ${ }^{5}$ Working Party Report, ${ }^{6}$ and the WTO agreements, ${ }^{7}$ to

is58vO8M_fAhWB8oMKHaZYAxcQFjAAegQICRAC\&url=https\%3A\%2F\%2Fww w.cfr.org \% 2Fcontent $\% 2$ Fpublications $\% 2$ Fattachments $\% 2 F S P R i n g 0315.09$-thru15.13.pdf\&usg=AOvVaw02vvzsinPIpS8ZGi60G4DJ [https://perma.cc/JJ4SWLP2].

3 These measures include the use of unilateral trade sanctions against China, i.e. trade sanctions imposed without consulting with and in defiance of the WTO. See Daniel C.K. Chow, United States Unilateralism and the World Trade Organization, 37 B.U. INT'L L. J. 1 (2019) [hereinafter Chow, United States Unilateralism)].

4 Daniel C.K. Chow \& Thomas J. Schoenbaum, International Business TRAnSACTIONS: Problems, CASES, AND MATERIAls 458 (Wolters Kluwer, 3d ed. 2015) [hereinafter CHOW \& SCHOENBAUM, INTERNATIONAL BUSINESS TRANSACTIONS]; see also 2017 USTR REPORT, supra note 1, at 2.

5 World Trade Organization, Protocol on the Accession of the People's Republic of China, WTO Doc., WT/L/432 (Nov. 23, 2001) https:/ / docsonline.wto.org/dol2fe/Pages/SS/DirectDoc.aspx?filename=t $\% 3 \mathrm{~A} \% 2$ Fwt\%2Fl\%2F432.doc\& [https://perma.cc/GGD9-EPGX] [hereinafter China Protocol of Accession]. China's Protocol of Accession was negotiated between China and other WTO members and sets forth the conditions of China's entry into the WTO.

6 World Trade Organization, Report of the Working Party on the Accession of China, WTO Doc. WT/ACC/CHN/49 (Oct. 1, 2000), https://www.wto.org/english/thewto_e/acc_e/wp_acc_china_e.doc [https://perma.cc/2XFE-R72H] [hereinafter China Working Party Report]. This document sets forth the negotiation history of China's accession into the WTO with other WTO members, led by the United States. In 1987, a working party was created to discuss the many conditions of China's entry into the WTO. The negotiation process took fourteen years, culminating in China's accession in 2001.

7 Upon China's accession to the WTO, China became bound to abide by all of the multilateral WTO agreements. See China Protocol of Accession, supra note 5 at art. 1. These are set forth in Annexes 1-2 of the Marrakesh Agreement Establishing the World Trade Organization and include the General Agreement on Tariffs and Trade 1994, the General Agreement on Trade in Services, the Agreement on Trade Related Intellectual Property Rights, and the Understanding on Rules and Procedures Governing the Settlement of Disputes. See Marrakesh Agreement Establishing the World Trade Organization, Apr. 15, 1994, 1867 U.N.T.S. 154, https://www.wto.org/english/docs_e/legal_e/04-wto_e.htm

[https://perma.cc/5E54-VMJ4] [hereinafter Marrakesh Agreement]. In addition, 
implement changes that would gradually replace its state-led economy with an economy based upon open market principles, consistent with the underlying foundations of the WTO. 8 China's failure to fulfill its WTO commitments has allowed China to reap the benefits of WTO membership and become a dominant trading nation while not allowing the United States to enjoy reciprocal benefits in obtaining access to China's markets. ${ }^{9}$ Moreover, China is actively harming U.S. interests with a host of mercantilist policies that discriminate against U.S. companies in China. ${ }^{10}$ Some of these specific arguments against China are not new to the Trump Administration but were also asserted by past U.S. administrations. For nearly two decades, since the administration of President Bill Clinton, the United States has asserted that China promised to dismantle the state sector and adopt an open market-oriented economy as part of its entry into the WTO. ${ }^{11}$

Despite these claims by the United States, however, an examination by this Article of the history of China's accession process and the relevant WTO documents indicates that China never pledged to dismantle its state-led economy and, as the United States asserts, to "move towards a true market economy." 12 The claim that China promised to implement free market reforms is a myth created by the United States as a result of wishful thinking, political expedience, and willful ignorance of China's major industrial policies and national initiatives developed and announced with great fanfare by China since the early 2000s shortly after China's entry into the WTO. ${ }^{13}$ These policies and initiatives boldly support the exact opposite conclusion: China is committed to strengthening the state sector, not dismantling it. ${ }^{14}$ This Article explains why China never made a commitment to dismantle the state sector, why China was under no WTO obligations when it acceded to the WTO in 2001,

\footnotetext{
like all WTO members, China became bound by many specialized agreements associated with GATT that are set forth in Annex 1A.

8 See 2017 USTR REPORT, supra note 1, at 2.

9 Id.

$10 \quad I d$

11 See infra Section II.B.

12 See 2017 USTR REPORT, supra note 1, at 2 (noting that bilateral trade talks with China have repeatedly failed, not due to the fault of U.S. policymakers, "but because Chinese policymakers were not interested in moving toward a true market economy.").

13 See infra Section II.B.

14 See infra Section III.A.
} 
and why the United States created this myth. China always intended to be a state-led economy as a member of the WTO. Given these realities, this Article explains the consequences for U.S. trade policy towards China for the future, which must be guided by the following three major points.

First, an examination of the documentary records surrounding the negotiations leading up to China's accession to the WTO indicates that China never promised to implement open marketoriented reforms that would dismantle the state sector. ${ }^{15}$ This claim was first asserted by President Bill Clinton to gain congressional approval for permanent Most Favored Nation (MFN) status for China in trade as part of China's accession to the WTO. ${ }^{16}$ Although China did indicate during the WTO negotiations that it would implement economic reforms, these reforms were to occur within the overall framework of a state-led economy. ${ }^{17}$ In addition, an examination of China's accession documents, including the Protocol of Accession, its Working Party Report, and the WTO agreements indicates that nothing in these WTO documents creates a legal obligation to adopt principles leading towards an open market economy. ${ }^{18}$ To be clear, China did make specific commitments under its Protocol of Accession, which set forth the conditions of its admission to the WTO, as well as under WTO agreements and China is arguably in breach of some of these specific obligations and the United States may be able to assert viable claims against China in the WTO dispute settlement system. ${ }^{19}$ But China's having committed breaches of specific obligations is not the same as refusing to live up to its promises to dismantle the leading role of the state sector in China's economy.

Second, the Communist Party of China (the Party), in power as China's rulers, has no intention of dismantling the state-led economy and replacing it with an open market economy. ${ }^{20}$ As explained below, the organization of China's economy as a state-led, mercantilist economy allows the Party to control all vital sectors of

\footnotetext{
15 See infra Part II.

16 See infra Section II.B. Most Favored Nation status was required for China to received favorable U.S. tariff rates. The MFN principle is further discussed in note 83 infra.

17 Id.

18 Id.

19 Id.

20 See infra Part III.
} 
the economy.21 For the Party, dismantling the state sector is equivalent to relinquishing power and opening itself up to challenges to its authority. ${ }^{22}$ The Party will not subject itself to this precarious fate. As further explained below, the Party sees its role as the savior of China due to reasons of history and destiny. ${ }^{23}$ No ruler of China in its entire history has ever voluntarily surrendered power. ${ }^{24}$ Chinese history and tradition indicate that the Mandate of Heaven, by which the emperor exercises legitimate power and holds the throne, is never voluntarily relinquished -it is forfeited. ${ }^{25}$ In addition to the lessons of history, there are also some of the deepest tendencies of human nature at play: the Party's control of the stateled economy has allowed members of the Party, from its highest ranks on down to the lowest, to amass vast personal wealth. ${ }^{26}$

Third, not only will China refuse to abandon the state-led economy, China will continuously strive to strengthen the role of the state for the foreseeable future. ${ }^{27}$ For the Party, strengthening the leading state sector further enhances its own power, further entrenches its role as China's ruler, and further promotes the individual interests of Party members. ${ }^{28}$ Under the leadership of President Xi Jinping, the Party has shown the tendency to further augment its power, not to diminish it. ${ }^{29}$ The best example of this tendency is $\mathrm{Xi}$ himself who has now installed himself as a de facto ruler-for-life in China. ${ }^{30}$ The United States must realize and accept that this is China's position. For years, the United States has engaged in trade negotiations with China with the goal of having China dismantle the state-led sector. ${ }^{31}$ The United States frequently claims that while China is willing to implement small scale changes,

21 See infra Part III.

22 Id.

23 See DANiel C.K. ChOW, The Legal System OF China In A NutShell 120 (3d ed. 2015) [hereinafter CHOW, LEGAL SYSTEM OF CHINA].

$24 I d$. at 121 ("In the more than 2,000 years of Chinese history dating back to the earliest Imperial Dynasty, the Eastern Zhou (771-256 BC), no ruling government of mainland China has ever voluntarily relinquished or transferred power to a succeeding government. No succeeding government has ever assumed power without destroying the presiding government.").

25 Id. The emperor also forfeits his life, along with his Mandate.

26 See infra Section III.C.

27 See infra Part IV.

28 See id.

29 See infra Section III.C.

30 See id.

31 See 2017 USTR REPORT, supra note 1, at 2-3. 
China is not willing to fundamentally change its system; 32 China makes promises that it will make fundamental changes to the stateled economy only to never follow through on those promises. ${ }^{33}$ The reality is that the Party has no intention of dismantling the state sector ${ }^{34}$, rather China will continuously develop a state-led economic system that is the opposite of the type of open market economy that the United States would like to see installed in China. ${ }^{35}$

To be clear, despite any U.S. claims to the contrary, China is a sovereign nation that has every right and the full freedom to adopt any economic system that it wishes. ${ }^{36}$ There is no inherent reason why an open market economy is superior in a moral or legal sense to a state-led economy. ${ }^{37}$ Countries that choose to trade with China do so freely and with knowledge of the drawbacks of dealing with China. ${ }^{38}$ If China made promises in the WTO to dismantle the state sector that it did not keep or is bound by WTO obligations to do so that it has breached, that is a valid complaint but this Article argues that China neither made such promises nor is bound by any such obligations. Moreover, it will become plain over the course of this Article that the Party has no intention of ever dismantling China's state-led economy. Given this position, if the United States believes that China's economy is fundamentally at odds with the WTO then the United States and other WTO countries are confronted with a plain choice: they must either negotiate new conditions for China to remain in the WTO as a state-led economy or seek China's exit from the WTO. ${ }^{39}$ The policy ramifications of this choice are further examined in the concluding portions of this Article below. ${ }^{40}$

This Article will proceed in four parts as follows. Part II will first discuss the U.S. complaints that China has not fulfilled its WTO commitments to dismantle the state sector and reform its economy in accordance with open market-oriented principles. Part II will also discuss the background of China's entry into the WTO. In the 1990s, China viewed WTO membership as a priority. ${ }^{41}$ One major reason

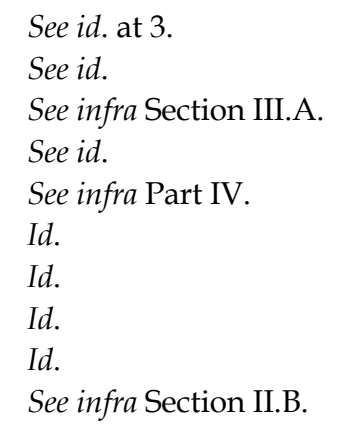


is that prior to China's WTO membership, China had to endure the annual humiliation of a review by the U.S. Congress of its human rights record in order to obtain MFN tariff rates, much lower than non-MFN rates, from the United States. ${ }^{42}$ WTO membership would allow China to obtain MFN tariffs rates as a matter of right. 43 Part II also discusses the legal documents supporting China's WTO entry and shows that they did not create any commitments on China to dismantle its state-led economy. Part III examines the critical role that the state-led economy and SOEs play in allowing the Party to control vital sectors of the economy. Part IV explains why the United States must accept the reality that China will not abandon the state-led economy or subject it to fundamental reforms so long as the Party remains in power. Part IV concludes with some observations for future U.S. trade policy concerning China.

\section{CHINA'S ACCESSION TO THE WTO AND THE MYTH OF OPEN MARKET REFORMS}

\section{A. China's State-Led Economy and the WTO}

The election of Donald J. Trump to the U.S. Presidency in 2016 led to a torrent of new criticism of China's trade practices, including, for the first time, a claim by a U.S. administration that it was a mistake to support China's entry into the WTO. Some of the sharpest criticism of China's trade practices are contained in two recent reports by the United States Trade Representative (USTR), the top U.S. trade official, ${ }^{44}$ submitted to Congress in 2018.45 According

$42 \quad I d$.

$43 \quad I d$.

44 See Daniel C.K. Chow \& Thomas J. Schoenbaum, International Trade LaW: Problems, CASES, AND MATERIALS 117 (3d ed. 2017) [hereinafter CHOW \& SCHOENBAum, InTERnATIONAL TRADE LAW] ("Appointed by the President with cabinet rank, the USTR is the chief official of the Executive Branch with respect to international trade.").

45 In addition to the 2017 USTR Report, supra note 1, on March 22, 2018, the USTR also submitted an executive office investigation brought under Section 301 of the Trade Act of 1974. See OfFICE OF THE U.S. TRADE RePrESENTATIVE, Findings OF the Investigation into China's Acts, Policies, AND Practices Related tO TeCHNOlogy Transfer, INTElLECTUAL PROPERTY, AND INNOVATION UNDER SECTION 301 OF THE TRADE ACT OF 1974 (Mar. 22, 2018) https:/ / ustr.gov/sites/default/files/ 
to the 2017 USTR Report, the underlying concern is that China continues to maintain a state-led economy. ${ }^{46}$ In the 2017 Report, the United States declared that "with the creation of the WTO, it was expected that each WTO member would pursue open, marketoriented policies..." 47 The United States expected that "the terms set forth in China's Protocol of Accession would dismantle China's existing state-led policies ..." 48 The United States further states:

It is important to recall that WTO members are supposed to be moving toward market-based outcomes voluntarily. The expectations of WTO membership were clearly set forth in the Marrakesh Declaration on April 15, 1994, at the conclusion of the Uruguay Round negotiations. There, WTO members expressly affirmed their view that the establishment of the WTO ushers in a "new era of global economic cooperation" that "reflect[s] the widespread desire to operate in a fairer and more open multilateral trading system." WTO members further made clear their determination that their economies would participate in the international trading system based on both "open, marketoriented policies and the commitments set out in the Uruguay Round Agreements and Decisions. 49

The crux of the U.S. grievances against China is that it has adopted a state-led mercantilist approach to international trade. 50 China uses myriad measures, practices, and policies to support its SOEs and other domestic Chinese companies in the internal China market while at the same time discriminating against multinational companies and other foreign companies. 51 On international trade,

Section\%20301\%20FINAL.PDF [https://perma.cc/QC6T-GYG9] [hereinafter USTR SPECIAL 301 REPORT]. On November 20, 2018, the USTR subsequently filed a report on China's laws, policies, practices, or actions. See OfFICE OF THE U.S. TRADE RePresentative, Update CONCERNING CHINA's ACTS, POlicies AND PRACTICES RELATED TO TECHNOLOGY TRANSFER, INTELLECTUAL PROPERTY AND INNOVATION (Nov. 20, 2018), https://ustr.gov/sites/default/files/enforcement/301Investigations/ 301\%20Report\%20Update.pdf [https://perma.cc/XJ2C-YLYD]. Both of these reports are highly critical of China's practices related to theft of U.S. intellectual property rights.

462017 USTR REPORT, supra note 1 , at 2.

$47 \quad I d$. at 5.

$48 \quad$ Id. at 2.

49 Id. at 5 (emphasis added).

50 Id. at 3 (stating that "China continues to pursue myriad mercantilist policies...").

$51 \quad$ Id. at 4. 
China's mercantilist policies strongly encourage and support exports while at the same time create significant barriers to imports.52 A major concern of the United States is China's use of subsidies, i.e. financial contributions from the government, 53 to support SOEs both within China and in export trade. The use of subsidies to encourage exports by SOEs is viewed as particularly pernicious in international trade because these subsidies allow SOEs to sell their exports at lower prices in the United States thereby harming U.S. companies and U.S. consumers. ${ }^{54}$

The United States singled out intellectual property rights (IPR) as a special area of concern that needed an independent investigation. On August 14, 2017, President Trump authorized the USTR to conduct an investigation of China's IPR practices under Section 301 of the Trade Act of 1974. ${ }^{55}$ In its report of the results of its investigation, the USTR identified four areas of concern: (1) China forces U.S. companies to transfer their technology (i.e., IPR) to SOEs as a condition of setting up operations in China; ${ }^{56}$ (2) China imposes discriminatory requirements on U.S. companies that license their technologies to Chinese entities so that the U.S. licensors are unable to obtain market terms in their licensing agreements; ${ }^{57}$ (3) China is acquiring U.S. companies through mergers and acquisitions and thereby also acquiring their IPR assets; 58 and (4) China is hacking into U.S. computer networks to acquire trade secrets from U.S.

52 White House Office of Trade \& Manufacturing Policy, How China's ECONOMIC Aggression THREATENS THE TECHNOLOGIES AND INTELlECTUAL PROPERTY OF THE UNITED STATES AND THE WORLD 1 (Jun., 2018) https://www.whitehouse.gov/wp-content/uploads/2018/06/FINAL-ChinaTechnology-Report-6.18.18-PDF.pdf [https://perma.cc/9SLB-Y24B] (stating that China's policies protect its home market from imports while expanding China's exports and share of global markets).

53 See ChOW \& SCHOEnbaum, InTERnATIONAL Trade LAW, supra note 44, at 467.

54 U.S. consumers and companies are harmed because after the lower priced exports create a market niche by driving out domestic competitors, the exporter can raise the price of its goods or lower their quality. See id. at 469.

55 The White House, Presidential Memorandum for the United States TRADE REPRESENTATIVE (Aug. 14, 2017) https://www.whitehouse.gov/ presidential-actions/presidential-memorandum-united-states-trade-

representative/ [https://perma.cc/Q2TT-65Y5]. The USTR conducts an annual review of intellectual property protection by its trading partners under Section 182 of the Trade Act of 1974, as amended by the Omnibus Trade and Competitiveness Act of 1988, the Uruguay Round Agreements Act, and the Trade Facilitation and Trade Enforcement Act of 2015, 19 U.S.C. § 2242 (2015).

56 USTR SPECIAL 301 REPORT, supra note 45 , at 5.

$57 \quad I d$.

$58 \quad I d$. 
companies and confidential information from the U.S. government. ${ }^{9}$ SOEs play significant roles behind the policies in all of these areas. 60

Given these are longstanding grievances that arise out of China's accession to the WTO, a question may arise as to why the United States has not asserted these claims within the WTO dispute settlement system. According to the United States, the WTO cannot address its grievances:

While the WTO agreements do include a dispute settlement mechanism, this mechanism is not designed to address a situation in which a WTO member has opted for a state led trade regime that prevails over market forces and pursues policies guided by mercantilism rather than global economic cooperation. The WTO's dispute settlement mechanism is narrowly targeted at good faith disputes where one member believes that another member has adopted a measure or taken an action that violates a WTO obligation .... [I]t is not effective in addressing a trade regime that broadly conflicts with the fundamental underpinnings of the WTO system. No amount of enforcement activities by other WTO members would be sufficient to remedy this type of behavior. ${ }^{61}$

\section{Id}

60 For example, in the case of technology transfers, the MNC may wish to set up a manufacturing facility in China. The MNC may be required by law to set up the manufacturing facility as a joint venture with a local Chinese partner. The local partner will be an SOE in the same industrial sector as the MNC. PRC authorities may require as a condition of approving the joint venture that the MNC transfer valuable technology to the joint venture. China's reasoning is that without advanced technology the joint venture will not be able to manufacture the product. If the MNC transfers technology to the joint venture, the SOE, as the local partner, also acquires access to the MNC's technology. The SOE can then use the technology for its own purposes or provide access to the technology to the Chinese government. MNCs claim that this is a form of "forced" technology because they are required to form a joint venture and provide its technology to the joint venture as a condition of entering the China market. In the second case above of discriminatory licensing requirements, the $\mathrm{MNC}$ may be required to license its technology to an SOE as a condition of being able to use the technology in China. In the third case of purchasing equity interests in U.S. companies, a Chinese entity, usually an SOE, will purchase the assets of a U.S. company and acquire all property interests of the U.S. company including its intellectual property portfolio. In all of these cases, SOEs can play a crucial role.

612017 USTR REPORT, supra note 1, at 5. 
Adding further to U.S. frustrations, not only has China failed to make any meaningful changes to its state-led economy to move towards an open market in the intervening years since WTO accession, instead, China has moved in the opposite direction by further strengthening the grip of the state and increasing the role of the state in its economy. ${ }^{62}$ All of this has occurred despite years of negotiations with the United States. ${ }^{63}$ Exasperated, the United States declared that since the "carrot" of negotiations with China has not worked, it is now time for the United States to brandish the "stick" of enforcement:

For more than 15 years, the United States has relied on cooperative high-level dialogues to effect meaningful and fundamental changes in China's state-led, mercantilist trade regime. These efforts have largely failed. Accordingly, the United States intends to focus its efforts on enforcement going forward .... The United States is determined to use every tool available to address harmful Chinese policies and practices ... Americans have waited long enough. The time has come for China to stop its market-distorting policies and practices and finally become a responsible member of the WTO. 64

Apparently, the Trump Administration believes that since the United States cannot persuade China through high-level dialogues to adopt market reforms and the WTO dispute settlement mechanism cannot discipline China, the United States will use threats, intimidation, and punitive measures in order to coerce China to adopt market reforms. The United States' enforcement arsenal "will include not only the use of the WTO's dispute settlement mechanism to hold China strictly accountable for adherence to its WTO obligations, but also other needed mechanisms, available under U.S. trade laws." 65 True to its word, in 2018, the United States plunged the global economy into a state of nervous uncertainty by imposing unilateral, punitive tariffs of $\$ 250$ billion on Chinese goods ${ }^{66}$ under U.S. trade laws without consulting

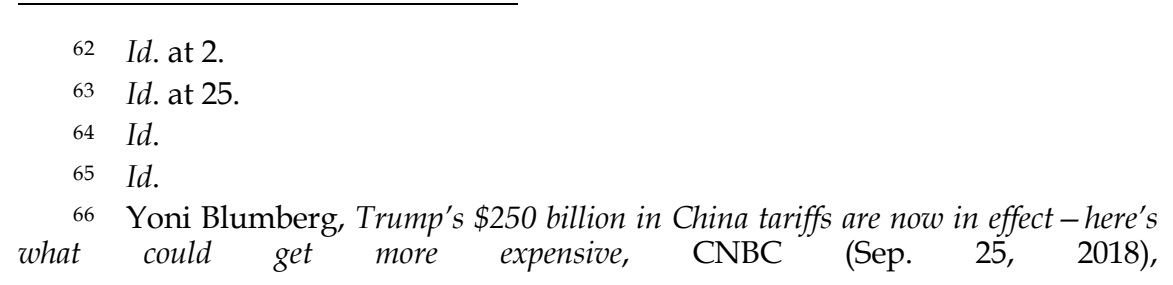


with and in defiance of the rules of the WTO. ${ }^{67}$ China immediately replied with retaliatory tariffs of $\$ 110$ billion on U.S. goods 68 setting the stage for a drawn out and destructive trade war, the full repercussions of which are yet to be determined.

\section{B. China's Accession to the WTO and Its Obligation to Implement Market Reforms}

\section{China, the GATT, and Most Favored Nation Tariffs}

As the crux of the U.S. grievance against China is its failure to fulfill its commitments to dismantle the state sector of its economy, we need to examine whether China made an explicit or implicit promise to adopt these commitments. We can start this analysis by examining the background and circumstances surrounding China's entry into the WTO. Although China was an original contracting party in 1947 to a predecessor organization of the WTO, the General Agreement on Tariffs and Trade (GATT), China withdrew from the GATT in $1950 .{ }^{69}$ In the late 1940s, China was in the midst of internal chaos and upheaval caused by a destructive civil war that erupted soon after the end of the Second World War. ${ }^{70}$ With the strong financial and military support of the United States, the Nationalist government, led by Chiang Kai-Shek, had a tenuous grip on power but soon became embroiled in a mortal conflict with the insurgent communist forces led by Mao Zedong. ${ }^{71}$ Against great odds, ${ }^{72}$ Mao

https:/ / www.cnbc.com/2018/09/25/with-trumps-250-billion-in-china-tariffsheres-what-will-cost-more.html [https:/ / perma.cc/HA6V-LN52].

67 Chow, United States Unilateralism, supra note 3.

68 Milton Ezrati, Trade War From the Chinese Side, Forbes (Oct. 3, 2018), https:/ / www.forbes.com/sites/miltonezrati/2018/10/03/trade-war-from-thechinese-side/\#141121296e10 [https://perma.cc/B735-BQPT].

69 Daniel C.K. Chow, Why China Opposes Human Rights in the World Trade Organization, 35 U. PA. J. INT'L L. 61, 71 (2013) [hereinafter Chow, Human Rights in the WTO].

$70 \quad I d$. at 72.

71 See CHOW, LeGAL System OF CHINA, supra note 23, at 13.

72 Chiang had an army that was twice the size of the Communists at the beginning of the conflict and also the advantage of American equipment and backing. See Id. While Chiang had material advantages, he was unable to overcome problems of incompetence in the field and corruption in command. Id. 
vanquished the Nationalist government to Taiwan. ${ }^{73}$ Mao then focused the new nation's energies on self-sufficiency, introspection, and revolutionary ideals; ${ }^{74}$ Mao had no interest in international engagement through trade but was focused on nation-building and national purification instead. ${ }^{75}$ After several decades marked by periods of calm interrupted by intermittent spasms of destructive political purges and chaos, China finally turned outward and focused on economic development in order to alleviate the abject poverty that the nation still suffered from its founding in 1949 through the decade of the 1970s and for most of its history. ${ }^{76}$ As China turned to trade, China found that it needed to join the GATT/WTO in order to receive favorable tariffs from GATT/WTO member nations and protections against discriminatory treatment. ${ }^{77}$ While China began negotiations for accession to the WTO in 1984, China's accession would not be completed until 2001.78 In the meanwhile, China faced a serious hurdle in the form of high tariffs on its goods from the United States, one of China's most important export markets. ${ }^{79}$

Imports from China enter the United States subject to the imposition by U.S. Customs of tariffs under the Harmonized Tariff Schedule of the United States (HTSUS), a practice that still holds today. 80 The HTSUS contains two general categories of tariffs applicable to imports that are set forth in two columns. ${ }^{81}$ In Column 1 are the Most Favored Nation (MFN) tariffs, i.e. favorable tariff rates that the United States applies to goods from other WTO

$73 \quad I d$.

74 Chow, Human Rights in the WTO, supra note 69, at 72.

75 Id.

$76 \quad$ Id. at 73 .

77 GATT/WTO members are entitled to the benefit of bound tariffs, i.e. tariffs subject to ceilings under the GATT/WTO and to MFN treatment, i.e. the lowest tariffs that a WTO member gives to any other nation. See General Agreement on Tariffs and Trade (GATT), art. II:1(a)-(b) (tariff bindings) and art. I (MFN principle), Oct. 30, 1947, 61 Stat. A-11, 55 U.N.T.S. 194.

78 See Press Release, World Trade Organization, WTO Successfully Concludes Negotiations on China's Entry (Sept. 17, 2001), https://www.wto.org/english/news_e/pres01_e/pr243_e.htm

[https:/ / perma.cc/ AG25-UJVL] (stating background information on China's entry into the GATT /WTO).

79 Chow, Human Rights in the WTO, supra note 69, at 75.

80 CHOW \& SCHOENBAUM, INTERNATIONAL BusinESS TRANSACTIONS, supra note 4 , at $137-38$.

81 Id. at 138 . 
members. ${ }^{82}$ All WTO members have the right to receive these tariffs under the MFN principle contained in GATT Article I. ${ }^{83}$ As most nations enjoy MFN tariffs under the HTSUS, the United States now eschews the use of the term "MFN" since it implies favoritism and instead uses the term "Normal Trade Relations" (NTR) to designate those nations that receive the Column 1 tariff rates. ${ }^{84}$ Under Column 2 of the HTSUS are the old Smoot-Hawley ${ }^{85}$ tariff rates implemented during the high tide of protectionism in the 1930s. ${ }^{86}$ Column 2 rates are draconian, averaging 53 percent of the value of the import, and were intended to prevent trade. ${ }^{87}$ Only a few pariah nations, such as North Korea, Cuba, and Iran, receive these rates under the HTSUS. ${ }^{8}$ In the 1990s, leading up to China's WTO accession, China

82 Id.

83 Id. Article I of the GATT requires the United States to grant all WTO members the most favorable tariff rates that it grants to any other nation, irrespective of whether the nation is a WTO member. This means that if the United States grants a low tariff rate to Country X then under the MFN principle the United States must automatically and unconditionally grant the same low tariff rate to every other WTO member. Countries are entitled to MFN treatment only if they are members of the WTO or otherwise have a treaty with the United States requiring MFN treatment. The availability of MFN treatment serves as an inducement for countries to join the GATT/WTO. See GATT, supra note 77, art. I. See also CHOW \& SCHOENBAUM, INTERNATIONAL TRADE LAW, supra note 44, at 150.

84 Id.

85 Smoot-Hawley Tariff Act of 1930, 19 U.S.C. ch. 4 (1930).

86 CHOW \& SCHOENBAUM, INTERNATIONAL Business TrANSACTIONS, supra note 4 , at $138-40$

87 CHOW \& SCHOENBAUM, INTERNATIONAL TRADE LAW, supra note 44, at 18.

88 CHOW \& SCHOENBAUM, INTERNATIONAL BUSINESS TRANSACTIONS, supra note 4, at 138-40 (discussing North Korea and Cuba as rogue states). North Korea, Iran, and Cuba are subject to numerous additional U.S. sanction regimes that impose independent restrictions limiting or preventing trade aside from Column 2 tariffs. In the case of North Korea, these sanction regimes include the National Emergencies Act, 50 U.S.C. §§ 1601-1655 (1976); International Emergency Economic Powers Act, Pub. L. No. 95-223, 91 Stat. 1625 (2007); North Korean Sanctions and Policy enhancement Act of 2016, Pub. L. No. 114-122, 130 Stat. 93 (2016); and Section 5 of the United Nations Participation Act of 1945, ch. 583, 59 Stat. 620 (1945). In the case of Cuba, these other regimes include the Trade Sanctions Reform and Export Enhancement Act, 22 U.S.C. $\$ \S 7201-7211$ (2000); Cuban Democracy Act of 1992, 22 U.S.C. ch. 69 §§ 6001-6010 (1992); Trading with the Enemy Act, 50 U.S.C. ch. 53 §§ 4301-4341 (1917); and Cuban Liberty and Democratic Solidarity (LIBERTAD) Act of 1966, Pub. L. No. 104-114, 110 Stat. (1966). In the case of Iran, these regimes include the Antiterrorism and Effective Death Penalty Act of 1996 (AEDPA), Pub. L. No. 104-132, 110 Stat. 1214 (1996); Comprehensive Iran Sanctions, Accountability, and Divestment Act of 2010, Pub. L. No. 111-195, 124 Stat. 1312 (2010); Iran Freedom and Counter-Proliferation Act of 2012, Pub. L. No. 112-239, 126 Stat. 2004 (2013); and Countering America's Adversaries Through Sanctions Act, Pub. L. No. 115-44, 131 Stat. 886 (2017). 
was also subject to the Column 2 Smoot-Hawley rates since it was not a WTO member and did not have a bilateral trade treaty with the United States granting MFN treatment. 89

In order to obtain MFN or NTR tariffs from the United States, China needed to obtain congressional approval on an annual basis subject to a review of China's human rights record. ${ }^{90}$ In 1971, the United States had passed the Jackson-Vanik amendment as part of the Trade Act of 1974 to pressure the Soviet Union to allow the emigration of Soviet Jews to the United States or Israel. ${ }^{91}$ The United States could approve MFN treatment for the Soviet Union based upon an annual certification of compliance or a presidential waiver excusing the application of the statute due to progress in the area of human rights. ${ }^{92}$ As the Jackson-Vanik amendment was drafted in general terms, the United States began to apply the amendment to China on an annual basis in determining whether to grant MFN treatment for Chinese goods. ${ }^{93}$ Congress had to "approve" China's human rights record each year as a condition of granting MFN tariffs. ${ }^{94}$

China's annual approval process for MFN treatment soon became a lurid spectacle of "China bashing" in which Congress scolded China for its poor human rights record and lectured China on how to cure its many deficiencies, only to approve MFN status

89 See Chow, Human Rights in the WTO, supra note 69, at 77-78 (explaining that because of its status as a non-GATT party state, China would receive the higher Column 2 Smoot-Hawley tariff rates unless it received an annual certificate of compliance with the Jackson-Vanik amendment to the Trade Act of 1974 or a presidential waiver therefor).

90 See id. at 77 ("[T] he United States agreed to extend the GATT rates to China based upon an annual approval of MFN status by the U.S. President. This approval was conditioned on an annual review of China's human rights record." (footnotes omitted)).

91 The Jackson-Vanik amendment was enacted into law as part of Title IV of the 1974 Trade Act, Pub. L. No. 93-617, 88 Stat. 1978, signed into law on Jan. 3, 1975 by President Gerald Ford. The amendment was designed to pressure the Soviet Union to allow ease of emigration for Jews. See Thomas J. Probert, The Innovation of the Jackson-Vanik Amendment, in HumANITARIAN InTERVENTION: A History 323 (Brendan Simms \& D.J.B. Trim eds., 2011) (describing the history of the amendment's passage).

92 Chow, Human Rights in the WTO, supra note 69, at 77.

93 See id. at 77-78 (describing how because the amendment uses general language, its application is not limited to any particular country).

94 Id. at 79 (describing the process by which Congress and the president would conduct annual approval and grant China its waiver). 
for China year after year. ${ }^{95}$ For its part, China, in the role of the contrite supplicant, endured this humiliating process in stoic silence and, in response to U.S. demands, made a few symbolic human rights gestures in order to obtain MFN status. ${ }^{96}$ To avoid having to suffer through this painful and degrading annual ritual, China sought to become a member of the WTO, which would grant MFN status as a matter of right. ${ }^{97}$ In addition, China's accession to the WTO would add much-needed predictability and certainty for its export trade by grounding MFN on a permanent legal basis and not on the whims of grandstanding U.S. politicians.98 Once China became a WTO member, then China would be entitled to MFN tariffs from the United States as a matter of right under the WTO, and the Jackson-Vanik amendment would become irrelevant.

\section{Clinton's Vision of China and the WTO}

China found a strong supporter of its cause in President Bill Clinton, who viewed China's WTO membership as an agent of potentially profound and positive change in China. ${ }^{99}$ In urging congressional approval for the granting of permanent MFN status to China as a result of its accession to the WTO, President Clinton argued that WTO membership would encourage positive political

95 See James A. Dorn, Time to Repeal the Jackson-Vanik Amendment, CATO INST. (Jul. 14, 1999), https://www.cato.org/publications/commentary/time-repealjacksonvanik-amendment [https://perma.cc/5PZL-SMLT] (arguing that the annual recertification process has been used too often to bash China).

96 See The Associated Press, China Releases 3 Prisoners in Gesture to U.S., N.Y. Times (Feb. 5, 1994), https://www.nytimes.com/1994/02/05/world/chinareleases-3-prisoners-in-gesture-to-us.html [https://perma.cc/68RE-USWD] (relaying how China released three political prisoners in a political gesture to obtain MFN treatment from the United States).

97 Every member of the GATT/WTO has a right to MFN treatment under GATT, Article I. GATT, supra note 77, art. I.

98 Id.

99 Eric Schmitt \& Joseph Kahn, The China Trade Vote: A Clinton Triumph; House, in 237-197 Vote, Approves Normal Trade Rights for China, N.Y. TIMEs (May 25, 2000), https:/ / www.nytimes.com/2000/05/25/world/china-trade-vote-clintontriumph-house-237-197-vote-approves-normal-trade-rights.html

[https://perma.cc/ZY5C-RVMS] [hereinafter Schmitt \& Kahn] (explaining how President Clinton "threw the powers of the presidency" behind the bill to approve normal trade rights for China). 
reforms in China, including greater protections for human rights. 100 Although negotiations for China's WTO accession had started during the Presidency of Ronald Regan, China's entry into the WTO would be a major achievement, and Clinton was eager to have this event occur before the end of his presidency.101 Addressing these concerns in a major speech on March 9, 2000 at Johns Hopkins University, Clinton made an explicit link between China's accession to the WTO and a commitment to adopt open market-oriented policies:

By joining the W.T.O., China is not simply agreeing to import more of our products; it is agreeing to import one of democracy's most cherished values: economic freedom. The more China liberalizes its economy, the more fully it will liberate the potential of its people .... And when individuals have the power[] not just to dream but to realize their dreams, they will demand a greater say. ${ }^{102}$

Clinton then made a critical link between economic freedom and political freedom:

There's something even more revolutionary at work here. By lowering the barriers that protect state-owned industries, China is speeding a process that is removing government from vast areas of people's lives .... [China] will have fewer instruments ... with which to control people's lives. And that may lead to very profound change.... [China] will find that the genie of freedom will not go back into the bottle. As Justice Earl Warren once said, liberty is the most contagious force in the world .... I understand that this is not in and of itself a human-rights policy. But still, it is likely to have a profound impact on human rights and political liberty. ${ }^{103}$

Clinton's reasoning is that by joining the WTO, China agreed to adopt "economic freedom" in the form of free markets; as a result, China would dismantle the state sector, and that would lead to political reform that would protect human rights. According to

100 Id. (describing President Clinton's argument that rejecting permanent MFN status "would undercut China's reformers").

101 Id.

102 President Bill Clinton, Speech on China Trade Bill (Mar. 9, 2000), https://www.iatp.org/sites/default/files/Full_Text_of_Clintons_Speech_on_Chi na_Trade_Bi.htm [https://perma.cc/K2HL-HH94] [hereinafter Clinton].

103 Id. 
Clinton, China could undergo nothing less than an economic and political revolution with its WTO accession and might even shed the shackles of communism in favor of democracy. ${ }^{104}$ Clinton dangled the prospect of democratic reform in China as the ultimate prize of China's entry into the WTO and congressional approval of permanent MFN or NTR status for China. The liberation of China from Communism would rectify one of the United States' most bitter disappointments of the Second World War when Mao Zedong and his guerilla communist forces overthrew the U.S.-backed government of Chiang Kai-Shek. ${ }^{105}$ This catastrophe was portrayed by Congress and the press at the time as the "loss of China" to communism and is referenced by Clinton at the beginning of his speech. ${ }^{106}$ For Clinton, the personal and professional stakes were high because China's potential embrace of democracy would be a crowning achievement for his presidency. ${ }^{107}$

In retrospect, these arguments seem to be illusory and quixotic, but at the time, a highly skilled politician marshaled them effectively before Congress and the American public. Whether these arguments are the result of wishful thinking or the expedient tactics of a crafty politician remains unclear. But this line of argument was repeatedly made by the Clinton Administration to gain political support for the congressional grant of permanent MFN or NTR status to China and appeared to gain currency within U.S. political discourse. ${ }^{108}$ This line of argument by Clinton appears to be the

104 See, e.g., Press Release, White House, The U.S.-China WTO Agreement Will Help Promote Reform, Accountability, and Openness in China (Mar. 8, 2000), https://clintonwhitehouse4.archives.gov/WH/New/html/20000308_2.html. [perma.cc/VN7C-LBJV] (providing several optimistic statements of potential political change in China from persons described as "Democracy and Human Rights Activists").

105 See CHOW, LEGAL SYSTEM OF CHINA, supra note 23, at 13 (describing the loss America felt when China fell to communism after hoping that it would become a democracy in Asia to counterbalance the Soviet Union).

106 Id. ("The loss of China to communism triggered a wave of bitter recriminations in the United States."); Clinton, supra note 102 ("At the dawn of the Cold War, when I was a young boy beginning to study such things, it was a cudgel in a political battle: 'Who lost China?'”').

107 Schmitt \& Kahn, supra note 99 (stating that President Clinton considered the passage of the bill to be "a crowning foreign policy triumph" of his presidency).

108 One indication of the extent to which Clinton's line of reasoning has gained acceptance in U.S. political discourse is that in 2017, Congress was still insisting that China's entry into the WTO came with commitments by China of political reforms and the development of the rule of law. See Hearing on The Broken Promises of China's WTO Accession: Reprioritizing Human Rights Before the Congressional-Executive 
genesis of the myth that China agreed to implement market reforms upon entry into the WTO.

\section{China's Views of Needed Reforms for the WTO}

In response to Clinton's grandiose vision of its future, a cautious China said nothing and made no bold promises. A perusal of China's WTO accession documents does not disclose any promises to dismantle the state sector and adopt open markets. In its Protocol of Accession, the formal document approved by the WTO that sets forth the specific terms and conditions of China's accession, there is not one mention of a commitment by China to adopt open market reforms. The Protocol of Accession contains specific WTO obligations, including the publication of laws, regulations, and other measures affecting trade in goods, services, or intellectual property rights; 109 the elimination of all taxes and charges applied to exports; $; 10$ and implementation of specific commitments in a schedule on agricultural products. 111 These are specific, concrete, and technical commitments that are legally binding, but China made no promises to introduce sweeping macro-economic policies or to dismantle the state sector.

China's expectations on its needed reforms as part of joining the WTO are discussed in the Working Party Report, which is a record of the negotiations between China, the United States, and other WTO members on China's accession. ${ }^{112}$ The Working Party Report is not legally binding except for Paragraph 342 (itself referring to numerous specific commitments), which was expressly incorporated in the Protocol of Accession. ${ }^{113}$ Otherwise, the Working Party Report is useful as a historical record in providing context and background for China's expectations in joining the WTO, explained as follows:

\footnotetext{
Commission on China, 115th Cong. 42 (2017) (statement of Michael R. Wessel, Commissioner, U.S.-China Economic and Security Review Commission) (stating that China had made commitments "in conjunction with the 1997 handover").

109 China Protocol of Accession, supra note 5, art. 2(C)(1).

110 Id. art. 11(3).

111 Id. art. 12(1).

112 China Working Party Report, supra note 6.

113 China Protocol of Accession, supra note 5, art. 1(2) (incorporating Paragraph 342).
} 
In statements to the GATT 1947 Working Party and subsequently to the Working Party on the Accession of China, the representative of China stated that China's consistent efforts to resume its status as a contracting party to GATT and accession to the WTO Agreement were in line with its objective of economic reform to establish a socialist market economy as well as its basic national policy of opening to the outside world. China's WTO accession would increase its economic growth and enhance its economic and trade relations with WTO Members. ${ }^{114}$

The Working Party Report indicates that China had an "objective of economic reform to establish a social market economy" as part of an overall objective of trading with the rest of the world.115 The concept of a socialist market economy, however, is not new to China's WTO accession. According to China's Ministry of Foreign Affairs, China has been developing a socialist market economy since the beginning of economic reforms in 1978.116 Today, the concept of a socialist market economy is fundamental to China. As embodied in Article 6 of the PRC Constitution:

The basis of the socialist economic system of the People's Republic of China is socialist public ownership of the means of production, namely, ownership by the whole people and collective ownership by the working people.... In the primary stage of socialism, the State upholds the basic economic system in which the public ownership is dominant and diverse forms of ownership develop side by side.117

The PRC Constitution makes it clear that in a socialist market economy, the state-led sector plays a dominant role. Article 7 of the PRC Constitution states: "The State-owned economy, namely, the socialist economy under ownership by the whole people, is the

\footnotetext{
114 China Working Party Report, supra note 6, at para. 4.

115 Id.

116 See The Socialist Market Economy: Introduction, MINISTRY OF FOREIGN AFFAIRS OF THE PEOPLE'S REPUBLIC OF CHINA, https://www.fmprc.gov.cn/mfa_eng/ljzg_665465/zgjk_665467/3582_665489/t17 865.shtml [https://perma.cc/8KJB-D6F4] (describing how "commodity, capital, labor service and technology markets have appeared one after the other in China" since 1978, transforming the planned economy system into a socialist market economy, and asserting that this transformation has strengthened the market's regulatory function "tremendously").

117 XIANFA art. 6 (2004) (China).
} 
leading force in the national economy. The State ensures the consolidation and growth of the State-owned economy."118

These official sources indicate that by "socialist market economy," China means that it will have a hybrid economy: stateled, with free-market features, and SOEs playing a decisive role. This concept is embedded in the PRC Constitution and has been recognized as guiding the country since 1978. These sources indicate that China's own views of its obligations to reform its economy as part of its accession to the WTO are far removed from the U.S.-described efforts of China's obligation to adopt a market economy. The grandiose vision of a China in which economic reform would lead inevitably to political reform and the growth of democracy was invented by Clinton and then accepted by subsequent U.S. administrations, including the current administration of President Trump.

\section{The WTO and Open Market-Oriented Policies}

Even if China never promised to adopt open-market reforms, China would be under a legal obligation to do so if any of the relevant WTO legal documents created such an obligation. To understand China's commitments, we now examine the immediate legal consequences of China's entry into the WTO. Under Article XII(1) of the Marrakesh Agreement on Establishing the WTO,119 China acceded to the WTO pursuant to its Protocol of Accession, which committed China to abide by the multilateral agreements of the WTO, i.e., the GATT (1994) ${ }^{120}$ covering trade in goods, the General Agreement on Trade in Services (GATS) ${ }^{121}$ covering trade in services, and the Agreement on Trade Related Intellectual Property

118 Id. art. 7.

119 Marrakesh Agreement, supra note 7; see also Protocols of accession for new members since 1995, including commitments in goods and services, WTO (last visited (Apr. 11, 2020), https://www.wto.org/english/thewto_e/ acc_e/completeacc_e.htm [https://perma.cc/LJ8Y-7BPB] (containing an official record of China's accession to the Marrakesh Agreement).

120 GATT, supra note 77; see also China Protocol of Accession, supra note 5.

121 General Agreement on Trade in Services (GATS), Apr. 15, 1994, Marrakesh Agreement Establishing the World Trade Organization, Annex 1B, 1869 U.N.T.S. 183, [https://perma.cc/S25Y-U6BH]. 
(TRIPS) ${ }^{122}$ covering trade in technology. A perusal of all of these agreements and their corollary agreements, ${ }^{123}$ including a description of general goals and policies contained in their preambles, shows no mention of a requirement to adopt open market-oriented reforms. Rather, these agreements contain specific obligations, many of them technical in nature.

The only WTO document supporting the U.S. position is the Marrakesh Declaration of 15 April 1994 marking the conclusion of the Uruguay Round of negotiations that established the WTO. In its preamble, the Marrakesh Declaration states that nations had participated in the Uruguay Round of negotiations "based upon open, market-oriented policies." 124 In its 2017 Report on China WTO Compliance to Congress, the USTR specifically quotes this language in the Marrakesh Declaration as the source of China's obligation to adopt open market-oriented reforms. ${ }^{125}$

The Marrakesh Declaration was issued by the highest decisionmaking body of the WTO, the Ministerial Conference, consisting of trade ministers from all members. ${ }^{126}$ The Marrakesh Agreement Establishing the WTO refers in numerous instances to the Ministerial Council ${ }^{127}$ and its decision-making powers, but while the Agreement describes the legally binding nature of decisions issued by the Ministerial Conference, it never mentions declarations. The Marrakesh Agreement makes it clear that the Ministerial Conference has the power to make "decisions" on all matters involving the WTO agreements "in accordance with the specific requirements for decision-making in this Agreement and in the relevant Multilateral Trade Agreement."128 The Marrakesh Agreement sets forth the

122 Trade-Related Aspects of Intellectual Property Rights (TRIPS), Apr. 15, 1994, Marrakesh Agreement Establishing the World Trade Organization, Annex 1C, 1869 U.N.T.S. 299, https://www.wto.org/english/docs_e/legal_e/27-trips.pdf [https://perma.cc/4SQP-ZK5C].

123 The GATT has twelve corollary agreements, including agreements dealing with agriculture, anti-dumping duties and subsidies, technical barriers to trade, and sanitary and phyto-sanitary measures; these are set forth in Annex 1A of the Marrakesh Agreement, supra note 7.

124 Marrakesh Agreement, supra note 7.

1252017 USTR REPORT, supra note 1 , at 5.

126 The Ministerial Conference meets every two years. See CHOW \& SCHOENBAUM, INTERNATIONAL TRADE LAW, supra note 44, at 28.

127 The Ministerial Council is also known as the General Council. It is the standing body of all of the trade ministers of WTO members who have permanent offices at the WTO headquarters in Geneva, Switzerland. Id.

128 Marrakesh Agreement, supra note 7, art. IV:1. 
voting requirements for a decision but not for a declaration. ${ }^{129}$ A Ministerial decision can affect rights under the WTO multilateral agreements by interpreting those agreements. ${ }^{130}$ Article XVI of the Marrakesh Agreement states: "Except as otherwise provided under this Agreement or the Multilateral Trade Agreements, the WTO shall be guided by the decisions, procedures and customary practices followed by the CONTRACTING PARTIES to GATT 1947 and the bodies established in the framework of GATT 1947."131

By contrast, a Ministerial declaration has no legal authority. This was made clear by the WTO panel in U.S. - Lead and Bismuth II, which explained:

A Ministerial Declaration is a mere "Declaration," rather than a "Decision" of the Ministers; a Declaration lacks the mandatory authority of a Decision; in the Ministerial Declaration, Ministers simply "recognize... the need" for the consistent resolution of disputes; the simple recognition of the need for an action does not mandate the action; in a Ministerial Decision, by contrast, Ministers "decide" that certain action shall be taken. ${ }^{132}$

The one textual support in the WTO for the U.S. position that China has an obligation to adopt "open, market-oriented policies" is a non-binding statement in a ceremonial declaration issued to mark the end of the Uruguay Round of negotiations; the statement may be aspirational in nature, but it is not mandatory according to WTO jurisprudence. This is hardly adequate legal support for the U.S. claim that China has failed to fulfill its commitments to replace its state-led sector with an open-market economy.

129 Id. art. IX:1 ("Decisions of the Ministerial Conference...shall be taken by a majority of the votes cast, unless otherwise provided in this Agreement or in the relevant Multilateral Trade Agreement").

130 Id. art. IV:1.

131 Id. art. XVI.

132 Panel Report, United States - Imposition of Countervailing Duties on Certain Hot-Rolled Lead and Bismuth Carbon Steel Products Originating in the United Kingdom, WTO Doc. WT/DS138/9/Corr.1 (June 27, 2000), https://docs.wto.org/dol2fe/Pages/FE_Search/FE_S_S006.aspx?Query=(@Symb $\left.\mathrm{ol}=\% 20 \mathrm{wt} / \mathrm{ds} 138 /{ }^{*}\right) \&$ Language=ENGLISH \&Context=FomerScriptedSearch\&lang uageUIChanged=true\# [https://perma.cc/26A2-SBGF]. 


\section{THE COMMUNIST PARTY AND THE STATE-LED ECONOMY}

\section{A. China's SOEs in the New Millennium}

The United States claims that it has, for the past fifteen years, engaged in good-faith negotiations with China, encouraging the state to follow through on its WTO obligations to dismantle its stateled sector of the economy. ${ }^{133}$ An examination of the recent history of China's industrial policies reveals that China has never indicated that it would abandon the state sector, but rather has consistently adopted policies to streamline and strengthen the state sector.

After the watershed year of 1978, as China shifted its focus from revolutionary ideals to economic development and foreign trade,134 China's policy makers faced the daunting task of reforming its massive state sector led by SOEs. ${ }^{135}$ The Party had to address the problem of persistent financial losses that SOEs suffered year after year, which were a major drain on the economy.136 By 1997, China had adopted a policy of selling off less vital SOEs to the private sector and focusing on supporting a smaller set of SOEs in strategic industrial sectors. ${ }^{137}$ This policy was Zhua Da Fang Xiao - "manage the large and let go the small."138 Although SOEs made up a smaller part of the economy as a result of these reforms, SOEs were maintained in all vital sectors of the economy, including banking, telecommunications, air and rail travel, steel and metals, oil and gas exploration and production, and electricity and water supply. ${ }^{139}$

1332017 USTR REPORT, supra note 1, at 2. ("U.S. policymakers hoped that the terms set forth in China's Protocol of Accession would dismantle existing state-led policies and practices that were incompatible with an international trading system expressly based on open, market-oriented policies and rooted in the principles of nondiscrimination, market access, reciprocity, fairness and transparency. But those hopes were disappointed.").

134 See CHOW, LEGAL SYSTEM OF CHINA, supra note 23, at 26-27 (explaining how following Mao's death in 1976, China "turned its attention to rebuilding [its] long[]neglected economy").

135 See id. at 29 (explaining the policies that China enacted to grant SOEs independent legal status and wean them off state subsidies).

136 See id. at 26 ("[China's] inefficient and poorly managed state sector resulted in the bulk of China's economy operating at a loss.").

137 See Beijing rules: China's state-owned enterprises, ECONOMIST (May 1, 1997), http://www.economist.com/node/148434 [https://perma.cc/F2TT-6BER].

$138 \mathrm{Id}$.

139 CHOW, LEGAL SySTEM OF CHINA, supra note 23, at 24. 
In 2003, only two years after China's accession to the WTO, the Party took a major step in increasing its control over SOEs when it established the State Owned Assets Supervision and Administration Commission ("SASAC"). ${ }^{140}$ The SASAC is a central level government agency that serves as the controlling shareholder of all SOEs in China, 141 allowing China to consolidate control over all SOEs in one entity. More than merely a holding company, the SASAC also actively manages its SOEs. ${ }^{142}$ The SASAC is perhaps the most powerful holding company in the world, controlling more than half of the Chinese SOEs on the global Fortune 500.143 Also in 2003, China established a second central level entity, Central Huijin Investment Ltd. (CHI), to increase its control over China's banks. ${ }^{144}$ The CHI serves as the controlling shareholder of China's banks, the lifeblood of the massive financial sector. ${ }^{145}$ China's top four largest commercial banks-the Bank of China, the Industrial and Commercial Bank of China, the China Construction Bank, and the Agricultural Bank of China - are larger than any U.S., European, or Japanese bank. ${ }^{146}$ As in the case of SASAC, CHI is not only a holding company but is an active manager of these banks. ${ }^{147}$ Together, the SASAC and CHI allow the state to control China's industrial and financial sectors, creating a firm grip over China's economy. ${ }^{148}$ SOEs implement the Party's initiatives in the industrial sector, and banks support SOEs by making loans to them under Party direction. ${ }^{149}$

In 2006, China announced a set of indigenous innovation policies designed to propel the nation forward in its race to become more globally competitive. ${ }^{150}$ Although announced in 2006, these policies

140 Mark Wu, The "China, Inc." Challenge to Global Trade Governance, 57 HaRV. J. INT'L L. 261, 271 (2016).

141 Id.

$142 \quad$ Id. at 272.

143 Id. at 271.

144 Id. at 274

145 Id.

$146 \quad I d$. at 273.

147 Id. at 274 .

148 Id. at $272,274$.

149 Id.

150 See China: Intellectual Property Infringement, Indigenous Innovation Policies, and Frameworks for Measuring the Effects on the U.S. Economy, Inv. No. 332-514, USITC Pub. 4199 (amended) at 5-1 (Nov., 2010), https://www.usitc.gov/publications/332/pub4199.pdf

[https://perma.cc/GLV2-SBTY] [hereinafter United States International Trade 
had antecedents in policies beginning in 1986 when the basic goals were first formulated. ${ }^{151}$ These indigenous innovation policies were a web of practices, policies, and measures designed to encourage the use of locally produced technology (i.e., IPR) and to wean China off the use of foreign-sourced technology.152 Among the most controversial of these policies were government-procurement policies that favored the purchase of products with indigenous innovation over products with foreign-sourced technology. ${ }^{153}$ The stated goal of these policies was to produce "national champion" companies, i.e., SOEs that could compete effectively with multinational companies in international business. ${ }^{154}$ U.S. companies have claimed that these policies discriminated against U.S. multinationals in China, and the United States has continuously pressured China to reform them. ${ }^{155}$

Coinciding with the announcement of its indigenous innovation policies, China began an aggressive expansion of business conducted by SOEs abroad by entering into trade agreements with mostly developing countries including Chile (2006), Pakistan (2006 and 2009), Singapore (2009), and Costa Rica (2010).156 China also entered into several multilateral trade agreements, including the Asia-Pacific Trade Agreement (2005) (China, Bangladesh, India, Laos, South Korea, and Sri Lanka) 157 and the Framework Agreement on Economic Cooperation with South East Asian Nations (2010)

Commission Report] ("In recent years, China has introduced a number of policies aimed at increasing the level of scientific and technological innovation originating within the country.").

151 See id. at 5-2 ("[M]any observers note that promoting innovation and technological development has long been an important theme for the Chinese government.").

152 Id. at 5-3.

153 Daniel C.K. Chow, China's Indigenous Innovation Policies and the World Trade Organization, 34 Nw. J. INT'L L. \& Bus. 81, 83 (2013) [hereinafter Chow, Indigenous Innovation Policies].

154 United States International Trade Commission Report, supra note 150, 5-6.

155 Chow, Indigenous Innovation Policies, supra note 153, at 84-85.

156 China maintains a website with its foreign trade agreements. See CHINA FTA NETWORK, http://fta.mofcom.gov.cn/english/index.shtml [https://perma.cc/3ALX-YKXL] (last visited Apr. 10, 2020).

157 U.N. Econ. \& Soc. Comm'n for Asia and the Pacific, Amendment to the First Agreement on Trade Negotiations among Developing Member Countries of the Economic and Social Commission for Asia and the Pacific (Bangkok Agreement), Asia-Pacific Trade Agreement (Nov. 2, 2005), https://www.unescap.org/sites/default/files/02_Amendment $\% 20$ to $\% 20$ Bangko k\%20Agreement.pdf [https://perma.cc/H784-U7CT]. 
(China, Brunei, Cambodia, Indonesia, Lao, Malaysia, Myanmar, Philippines, Singapore, Thailand, Vietnam, and other nations). ${ }^{158}$ These agreements pave the way for SOEs to expand their operations in foreign countries under terms that do not contain restrictions related to workers' rights, labor conditions, and the environment. 159 The lack of these constraints allow SOEs from China to operate with lower costs than multinational companies from the United States that are subject to myriad constraints on their behavior under U.S. treaties and federal law. 160 In 2016, China established the Asia Infrastructure Investment Bank (AIIB) to serve as a rival to the U.S.backed World Bank.161 A major purpose of the AIIB is to provide funding for major infrastructure projects in Asian countries that will be implemented by China's SOEs. ${ }^{162}$ In other words, China will lend money through the AIIB to foreign countries who will then use the funds to pay China's SOEs to implement infrastructure projects.

In 2013, at the conclusion of the Third Plenum of the Communist Party, the Party reaffirmed its support of SOEs when it announced that it would "incessantly strengthen [the] vitality" of SOEs. ${ }^{163}$ The Party reiterated its support for SOEs for the near future - up to 2025 and beyond - when in 2015, China announced a major new policy initiative, "Made in China 2025." 164 This initiative advances themes proposed by the indigenous innovation policies announced in

158 Framework Agreement on Comprehensive Economic Co-Operation Between the Association of South East Asian nations and the People's Republic of China (Nov. 4, 2002), https://wits.worldbank.org/GPTAD/PDF/ archive/ASEAN-China.pdf [https://perma.cc/2459-UCCL].

159 Daniel C.K. Chow, How China Promotes Its State-Owned Enterprises at the Expense of Multinational Companies in China and Other Countries, 41 N.C. J. INT'L L. 455, 486-87 (2016) [hereinafter Chow, How China Promotes its SOEs].

$160 \quad$ Id. at 487.

161 Daniel C.K. Chow, Why China Established the Asia Infrastructure Investment Bank, 49 VAND. J. TRANSNAT'L L. 1255, 1256, 1258-59 (2016).

162 Id. at 1293-94 (explaining that "China can promote SOEs by using the AIIB to make loans to developing countries to fund infrastructure projects that will be implemented by SOEs. In other words, China may use the AIIB to lend money to other countries to buy Chinese goods and services from SOEs.").

163 Bob Davis \& Brian Spegele, State Companies Emerge as Winners Following Top China Meeting: Enterprises Fended Off Calls to Curb Their Influence, WALL STREET J. (Nov. 13, 2013), https://www.wsj.com/articles/state-companies-emerge-aswinners-following-top-china-meeting-1384352718 [https://perma.cc/RU5WSDFP].

164 U.S. Chamber of COMMERCE, MAde In China 2025: Global AMbitions Built ON LOCAL PROTECTIONS, 6 (2017), https://www.uschamber.com/sites/ default/files/final_made_in_china_2025_report_full.pdf [https://perma.cc/3EJRKYCV]. 
2006.165 Under Made in China 2025, the goal is for China to move further up the value and technology chain and become a leader in global manufacturing. 166 Among the ten industries singled out for development under Made in China 2025 are advanced information technology, aerospace and aviation equipment, advanced rail equipment, biomedicine and high-performance medical devices, and agricultural machinery. ${ }^{167}$ Made in China 2025 envisions a three-part strategy: localize innovation, replace foreign-sourced technology with locally created technology, and capture domestic and international market share in the ten strategic industries. ${ }^{168}$ In 2016, China once again reiterated the leadership role of SOEs in a national meeting on building the role of the Party within SOEs. 169 President $\mathrm{Xi}$ emphasized the role of the SOE as an instrumentality of the Party and announced that Party leadership and increasing the role of the Party are "the root and soul" of SOEs. 170

These developments indicate that after China's accession to the WTO in 2001, China has regularly adopted major policy initiatives that strengthened the Party's grip over the economy and has announced plans for SOEs to become leaders in global business. The Party has sought to further embed itself in SOEs to the point where the two now seem to be fused together.

\section{B. Party Control of the Economy through the State Sector}

The Party is able to exercise pervasive control over SOEs and, through SOEs, all vital sectors of China's economy. Within SOEs, organizational structures allow the Party to exercise control at the management level but also in the day-to-day affairs of the company.171 Within each SOE, there are two parallel management

165 Id. at App. 1.F (listing “Overlapping Plans").

166 Id. at 9.

167 Id. at 6.

168 Id. at 13.

169 See Xi stresses CPC leadership of state-owned enterprises, CHINA DAILY (Oct. 12, 2016), https://www.chinadaily.com.cn/china/2016-10/12/content_27035822.htm [https://perma.cc/V52X-3LVE] ("Efforts should be made to strengthen and improve Party leadership, as well as to build the role of the Party in SOEs to make them the most trustworthy and reliable forces of the CPC and the state, said Xi.").

$170 \quad$ Id.

171 See Chow, How China Promotes its SOEs, supra note 159, at 468 (describing the two parallel management structures of SOEs). 
structures: one is the corporate management structure consisting of a chief executive officer, one or more vice chief executive officers, a chief accounting officer, and a board of directors. ${ }^{172}$ This type of management structure is similar to corporate organizations in the United States. A second parallel structure is the Party organization: the Party structure consists of a secretary of the Party (the highest position), several deputy secretaries, and a secretary of the Discipline Inspection Commission (the word "Discipline" is a surrogate for the more threatening sounding "corruption"). ${ }^{173}$ Each person who holds a position in the corporate management structure simultaneously holds a position of equal rank within the Party structure, with the Party position as the more powerful. ${ }^{174}$ As the Party organization must meet regularly, Party members are able to carry out the directives of the Party at the enterprise management level and also at the level of day-to-day operations. ${ }^{175}$ This structure also exists at all levels of the government (central, provincial, and local). ${ }^{176}$ This is the key structure through which the Party controls the State. The supervision of the SASAC, discussed above, helps to ensure that Party management of SOEs is consistent across industrial sectors. The SASAC regularly rotates personnel between the SASAC and SOEs. ${ }^{177}$ This rotation deepens the cooperation between the SOEs and the state. ${ }^{178}$

SOEs are more than just important economic actors in China. SOEs also serve as the mechanism by which the Party is able to exercise pervasive control over the economy. Given this role, dismantling SOEs would mean that the Party would relinquish significant power. Instead of dismantling SOEs, the Party promotes and protects them. ${ }^{179}$

$\begin{array}{ll}172 & I d . \\ 173 & I d . \\ 174 & I d . \\ 175 & I d . \\ 176 & I d . \\ 177 & I d . \\ 178 & I d . \\ 179 & I d \text {. at } 469 .\end{array}$




\section{Party Control and Personal Wealth}

A consequence of the Party's control of the economy is that members of the Party have been able to acquire immense personal wealth despite modest official salaries. ${ }^{180}$ In 2012, the New York Times published an article detailing the personal and family wealth of Wen Jiabao, then China's Premier, ${ }^{181}$ often portrayed in the media as a benevolent figure known as "Uncle Wen." 182 The article details a Wen family fortune worth $\$ 2.7$ billion with holdings in telecommunications, real estate, and insurance. ${ }^{183}$ Wen's 90 -year old mother alone had \$120 million in investments in an insurance company. ${ }^{184}$ The article notes that Wen's family fortunes soared off the charts after his elevation to power as premier. ${ }^{185}$ In 2014, after an investigation of Zhou Yongkang, a former Minister of Public Security and senior Party member, China seized assets worth $\$ 14.5$ billion from Zhou's family and associates. 186 Some of this wealth is ostentatious. The disgraced former senior Party member Bo Xilai's holdings included a multi-million-dollar lakeside villa in Cannes, Southern France. ${ }^{187}$

$180 \mathrm{Xi}$ Jinping, for example, earns about $\$ 22,000$ a year as the President of China. Lily Kuo, Does Chinese president Xi Jinping really earn just \$22,000 a year?, QUARTZ (Jan. 20, 2015), https:/ / qz.com/329584/does-chinese-president-xi-jinpingreally-earn-just-22000-a-year/ [https://perma.cc/MUM5-XT8E] (discussing widespread perception that Party officials are corrupt).

181 David Barboza, Billions in Hidden Riches for Family of Chinese Leader, N.Y. TIMES (Oct. 25, 2002), https://www.nytimes.com/2012/10/26/ business/global/family-of-wen-jiabao-holds-a-hidden-fortune-in-china.html [https://perma.cc/ZWB6-QT5N].

182 See, e.g., Dhara Ranasinghe, Expose on Wen Jiabao's Wealth-Storm in a Teacup?, CNBC (Nov. 11, 2012), https://www.cnbc.com/id/49719053 [https://perma.cc/4PXA-XEJU] (describing a potential scandal where many of Wen's relatives "became extraordinarily wealthy during the premier's term in office").

183 Barboza, supra note 181.

184 Id.

185 Id.

186 Benjamin Kang Lim \& Ben Blanchard, Exclusive: China seizes \$14.5 billion assets from family, associates of ex-security chief: sources, WORLD NEWS (Mar. 30, 2014), https:/ / www.reuters.com/article/us-china-corruption-zhou/exclusive-chinaseizes-14-5-billion-assets-from-family-associates-of-ex-security-chief-sourcesidUSBREA2T02S20140330 [https:// perma.cc/7U6R-B4Q8].

187 Yao Meng, Bo Xilai's Cannes villa goes on sale, GLOBAL TiMEs (Dec. 22, 2014), http://www.globaltimes.cn/content/898165.shtml [https://perma.cc/QNM2NX3Q] (stating that Bo's villa was put on sale for $\$ 8.52$ million). 
In 2013, with his ascension to power as President, Xi Jinping launched a major crackdown on corruption. ${ }^{188}$ As of 2018, the crackdown has punished an astonishing 1.5 million corrupt Party officials.189 Critics of $\mathrm{Xi}$, however, argue that his anti-corruption campaign is motived not by altruistic goals but by a desire to root out his enemies and consolidate his power. ${ }^{190}$ In 2018, riding a wave of popularity due in part to his stance against corruption in the Party, $\mathrm{Xi}$ was able to remove term limits on his presidency, allowing him to serve for life. ${ }^{191}$ Critics further argue that corruption is built into the structure of China's governing institutions and that Xi's goal is not to wipe out corruption but to manage it for his own political purposes. ${ }^{192}$ According to these observers, Xi shows little interest in making the types of institutional reforms that would truly root out and eliminate corruption. ${ }^{193}$ It appears to be likely that Party members - at least those not out of favor with $\mathrm{Xi}$ - may be able to continue to amass and retain private fortunes. For example, Wen never faced any consequences after the New York Times exposé about his family wealth. Instead, the Party was infuriated by the Times article and punished the New York Times by blocking it from China's websites, ${ }^{194}$ a ban that remains in effect to this day, more than six years later. Another prominent example is Xi himself, whose family

188 Daniel C.K. Chow, Why China's Crackdown on Commercial Bribery Threatens U.S. Multinational Companies Doing Business in China, 31 ARIZ. J. INT'L \& COMP. L. 511, 518 (2014) (describing Xi's crackdown efforts and his view that corruption "could kill the Party and ruin the country").

189 Eric Baculinao, China's President Xi beefs up his anti-corruption crackdown, NBC News (Feb. 27, 2018), https://www.nbcnews.com/news/china/china-spresident-xi-beefs-his-anti-corruption-crackdown-n851491 [https://perma.cc/ZEP6-AD59].

190 See, e.g., David Skidmore, Understanding Chinese President Xi's anticorruption campaign, CONVERSATION (Oct. 27, 2017), http://theconversation.com/understanding-chinese-president-xis-anti-

corruption-campaign-86396 [https://perma.cc/GJ5M-KMHU] (arguing that Xi's campaign is motivated not by "his own rectitude" but rather by a desire to ensure that only those who help him stay in power receive kickbacks).

191 China reappoints Xi Jinping as president with no term limit, GUARDIAN (Mar. 17, 2018), https://www.theguardian.com/world/2018/mar/17/chinareappoints-xi-jinping-as-president-with-no-term-limit [https://perma.cc/P43L638P].

192 Skidmore, supra note 190.

193 Id.

194 See Keith Bradsher, China Blocks Web Access to Times After Article, N.Y. TIMES (Oct. 25, 2012), https://www.nytimes.com/2012/10/26/world/asia/chinablocks-web-access-to-new-york-times.html [https://perma.cc/XR53-FE6J]. 
has been able to accumulate over $\$ 1$ billion in personal wealth, 195 despite Xi's very modest government salary. ${ }^{196}$ Although the current anti-corruption campaign is noted for its intensity and duration, most people in China continue to hold a cynical view of Party members. ${ }^{197}$ SOEs are notoriously corrupt, 198 and many believe that Party officials at all levels are able to acquire wealth through their positions and their control of SOES and the economy. 199

\section{CONCLUSION}

The Trump Administration's claim that the United States erred in supporting China's entry into the WTO is based upon a flawed premise. This premise is that China made an explicit or implicit commitment to dismantle its state-led economy in favor of eventually establishing an open market economy. China never made such a commitment and China is not otherwise bound by any legal obligations found in the WTO to do so. Perhaps China is "guilty" of allowing Clinton to trumpet the possibility of democratic reform as a result of its accession to the WTO without correcting him. If that is the extent of China's culpability, then China has done no more than take advantage of a wrong-headed opponent by allowing him to reach the conclusions he wanted for political reasons. If an error was involved, it was on the part of the United States, which, due to wishful thinking, political expediency, or a combination of both, falsely convinced itself that China made a commitment to fully embrace open-market oriented reforms and eventually dismantle the state sector of the economy.

Not only has China not retreated from a state-led economy, China has been unwavering in strengthening it beginning shortly after its accession to the WTO. A series of major policy initiatives, declared with great fanfare and in plain sight starting shortly after China's accession, indicates that the Party has no intention of abandoning China's state-led economy but seeks to elevate it. China

195 Skidmore, supra note 190.

196 Xi's official salary is $\$ 22,000$ per year. See Kuo, supra note 180.

197 This observation is based on the author's own discussions in China with lawyers, academics, and citizens of China.

198 See Chow, How China Promotes its SOEs, supra note 159, at 488.

199 See Schmitt \& Kahn, supra note 99. 
now has ambitious plans to lift its SOEs to the top level of international competition in the most advanced industries in the world by 2025. China also plans to further elevate and entrench the role of the Party in SOEs. To believe that China will abandon the state sector in light of these developments is pointless and naïve. Such a belief also ignores the forces of Chinese history and tradition.

The Party is a devoted student of Chinese history, tradition, and culture and China is a country that is perhaps more bound by these forces than most. President $\mathrm{Xi}$ has stated that the "values and spiritual world of the Chinese people have always been deeply rooted in the fertile soil of China's traditional culture." $200 \mathrm{Xi}$ also stated that "the Chinese Communist Party is the successor to and promoter of fine traditional Chinese culture." 201 In the context of Chinese culture, the Party sees its ascension to power in China in heroic terms and as a matter of destiny.202 The PRC Constitution states that after years of domination by foreign nations, China was reduced to a "semi-colonial country" 203 and waged many "heroic struggles for national liberation and independence."204 After "protracted and arduous struggles ... along a zig zag course" 205 the Communist Party led by Mao finally "overthrew the rule of imperialism, feudalism and bureaucrat-capitalism" 206 and achieved "a great victory in the New-Democratic Revolution." 207 Through the Party the Chinese people finally became the "masters of the country." 208 The implication of the Constitution is that only the Party was able to emerge from the chaos of the twentieth century to save the Chinese people from foreign oppression and internal decay.

Like the emperors of China that preceded it, the Party seized power through bloodshed and violent overthrow by vanquishing a ruling government that had succumbed to moral corruption. 209 Chinese history and philosophy teach that an emperor ruled

\footnotetext{
200 Jin Kai, The Chinese Communist Party's Confucian Revival, DiPlomat (Sept. 30, 2014), https://thediplomat.com/2014/09/the-chinese-communist-partysconfucian-revival/[https://perma.cc/W8AQ-3FV7]

201 Id.

202 See CHOW, LEGAL SYSTEM OF CHINA, supra note 23, at 121.

203 XIANFA, pmbl. (1982) (China).

$204 \quad I d$.

$205 I d$.

206 Id.

207 Id.

208 Id.

209 See CHOW, Legal System OF CHINA, supra note 23, at 120-21.
} 
through the "Mandate of Heaven" (i.e. legitimate power) and continued in power until he lost it by descending into tyranny or moral decay. ${ }^{210}$ At that point, a new leader with a new Mandate of Heaven will appear to depose the sitting leader and assume the throne. ${ }^{211}$ Every emperor of China held the Mandate of Heaven until he was deposed.212 Just as throughout Chinese history the Mandate of Heaven is never voluntarily relinquished but is forfeited, the Party sees itself as holding onto the Mandate of Heaven until it is forfeited. ${ }^{213}$ The notion that the Party will voluntarily abandon its seat of power in favor of a democracy is naïve and against the tide of Chinese history, culture, and philosophy in which the Party holds a deep belief. Adding to the forces of tradition are also the deepest tendencies of human nature. Party members enjoy great power and personal wealth under the current system. ${ }^{214}$

The United States now admits that its efforts to push, prod, or cajole China into adopting open market-oriented reforms within the WTO have been largely futile. The Trump Administration seems to have concluded that seeking China's reform through the use of the WTO, including its dispute settlement system, will be ineffective in achieving open market-oriented reforms in China. Instead, the United States has adopted an approach of imposing unilateral trade sanctions on China outside of and in contravention of the WTO.215 This approach aims to coerce China into adopting changes that China would not accept through WTO negotiations.216 China has responded with indignation and defiance by imposing retaliatory measures against the United States.217 Since President Trump first imposed new tariffs on steel and aluminum from China and other nations on March 23, 2018,218 the two protagonists have been locked in a dangerous and escalating tit-for-tat tariff war. ${ }^{219}$

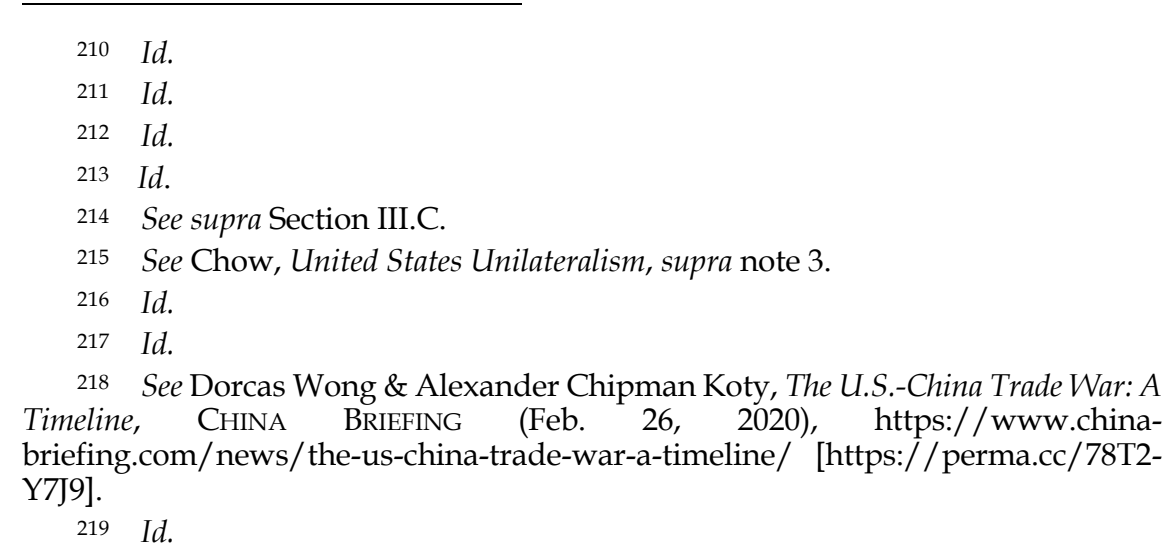


On January 20, 2020, the United States and China entered into Phase One of the Economic and Trade Agreement between the United States and China ${ }^{220}$ designed to resolve the trade dispute between the two countries. Under Phase One, China made numerous significant commitments in intellectual property protection $^{221}$ and dispute resolution 222 and also committed to purchase at least $\$ 200$ billion in goods from the United States in the next two years.223 What is significant about the Phase One agreement is that it contains no obligations on the part of China to reform its state-led economy.224 China rebuffed talks on this subject during the Phase One negotiations. ${ }^{225}$ The United States hopes to obtain concessions on this issue, the most difficult and intractable of all in the two countries' negotiations, for Phase Two of the agreement to be reached in the next round of negotiations. ${ }^{226}$

Will these negotiations allow the United States to obtain a firm, specific commitment from China to dismantle its state-led economy, a goal that the United States could not achieve within the WTO? Based on the discussions in this Article, the United States cannot be optimistic. The United States can expect that China will continue to rebuff talks on this subject. Even if China agrees to talks, it will be

220 Economic and Trade Agreement between the Government of the United States of America and the Government of the People's Republic of China ("Economic Agreement between U.S. and China"), U.S.-China, Jan. 15, 2020, https:/ / ustr.gov/sites/default/files/files/agreements/phase $\% 20$ one $\% 20$ agreem ent/Economic_And_Trade_Agreement_Between_The_United_States_And_China _Text.pdf\%20 [https://perma.cc/99SG-SGAT].

221 The entire first chapter deals with intellectual property protection and imposes many new obligations on China. Chapter 2 deals with new obligations by China relating to technology transfer, also related to intellectual property. See id. at 1-1 to 1-18 (intellectual property), 2-1 to 2-3 (technology transfer).

222 See id. at ch. 7 (allowing the United States to unilaterally impose trade sanctions on China in the event of China's failure to fulfill its obligation under the Agreement and to prohibit China from adopting a counter-response); see also id. at ch. 7.4:4(b), 7-3.

223 See id. art. 6.2 ("China shall ensure that purchases and imports into China from the United States of the manufactured goods, agricultural goods, energy products, and services identified in Annex 6.1 exceed the corresponding 2017 baseline amount by no less than $\$ 200$ billion.").

224 See Peter Eavis, et al., What's In (and Not in) in the New U.S.-China Trade Deal, N.Y. TIMES (Jan. 15, 2020), https://www.nytimes.com/2020/01/15/business/ economy/china-trade-deal-text.html [https://perma.cc/XT3F-MC2P] (noting that the U.S. has "long had concerns about China's use of industrial subsidies and stateowned enterprises to build up and dominate crucial industries" but "China rebuffed talks on these subjects" $)$.

225 Id.

$226 I d$. 
difficult to obtain firm commitments from China to dismantle its state-led economy and any commitments obtained from China are likely to be illusory. The Agreement contains a provision that allows China to terminate it at any time by the submission of a notice of withdrawal.227 The United States should be aware that China's strategy may be to agree to Phase Two just to avert a destructive trade war, then delay the implementation of commitments, if any are reached, to reform its state-led economy, and then to withdraw from the Agreement once the simmering effects of the trade war have passed and China is in a stronger position to resist further U.S. attempts at intimidation. The negotiations of Phase Two and the conclusion and implementation of the agreement bear careful watching in the next several years to come.

At this point, let us be clear that there is nothing legally or morally wrong with China's choice of an economic or political system. Despite the U.S. claims to the contrary there is no reason why a sovereign nation that adopts a state-led economy over an open market economy is in moral, legal, or historical error. ${ }^{228}$ Once the U.S. claim that China has a legal obligation to adopt an open market economy is debunked, China, like any other sovereign nation, has the right and full freedom to adopt any economic or political system that it sees fit regardless of criticism from the United States.229 Other nations have the freedom to trade with China as they wish or to enter into disputes over trade with China as they see fit.230 But in these disputes no nation, including the United States, has the higher moral or legal ground.231

Frustrated with the lack of progress in dealing with China within the WTO, the United States is now determined to work outside of the WTO and deal with China directly through the use of economic

227 Economic Agreement between U.S. and China, supra note 220, art. 8.3:2 (stating that a notice of termination becomes effective 60 days after submission to the other party or on any other on which the parties agree).

228 It is possible to derive these freedoms from the fundamental principle of sovereign equality of nations as set forth in Article 2(1) of the Charter of the United Nations, U.N. Charter art. 2(1), http://legal.un.org/repertory/art2.shtml [https://perma.cc/HUX9-QMHP]. See also Hans Kelsen, The Principle of Sovereign Equality of States as a Basis for International Organization, 53 YALE L.J. 207 (1944).

$\begin{array}{ll}229 & \text { See id. } \\ 230 & \text { Id. } \\ 231 & \text { Id. }\end{array}$


might. ${ }^{232}$ Despite the progress reached by concluding Phase One of the Economic Agreement to end the trade war, ${ }^{233}$ the ability of the United States to secure and enforce an obligation by China to implement open market reforms through this process is far from certain. Moreover, regardless of the effectiveness of the U.S approach to China outside of the WTO, the United States must still address the issue of what to do about China's future in the WTO.

It should be clear that China's status quo in the WTO is not acceptable. The article has shown that the present approach of coaxing China to adopt open market reforms in the WTO is futile, traceable to a myth and a hopeful illusion. It should also be clear that doing nothing is also not acceptable. China has been able to exploit the benefits of its WTO membership to become dominant in world trade with a state-led economy that cannot be reined in by the rules of the WTO. China will only become more dominant in the WTO and world trade if the United States does nothing.

At this point, the United States is realistically faced with only two choices. The United States can seek to have China renegotiate its terms of membership in the WTO and impose the type of effective constraints that will allow the WTO to discipline China's state-led economy and control its WTO inconsistent practices. ${ }^{234}$ One

2322017 USTR REPORT, supra note 1, at 5 ("The notion that our problems with China can be solved by bringing more cases at the WTO alone is naïve at best, and at worst it distracts policymakers from facing the gravity of the challenge presented by China's non-market policies); see also Bob Davis, When the World Opened the Gates of China, WALL STREET J. (July 27, 2018), https:/ / www.wsj.com/articles/when-theworld-opened-the-gates-of-china-1532701482 [https://perma.cc/XT3F-MC2P] (quoting Robert Lighthizer, the USTR, stating in reference to using economic muscle against China, "Ultimately, that's all you have anyway.").

233 See supra text accompanying notes 220-26.

234 One need look no further than to the Trans-Pacific Partnership (hereinafter "TPP") for a set of legal constraints that are designed to reign in China's state-led economy. The TPP is a mega free-trade agreement with the United States and 11 Asian economies that was drafted by the United States with the primary goal of limiting China's state-led economy in international trade. See Daniel C.K. Chow, How the United States Uses the Trans-Pacific Partnership to Contain China in International Trade, 17 CHI. J. INT'L L. 370, 374 (2017). The United States negotiated the TPP but excluded China from the negotiations. Id. at 372. Once the TPP was complete, the United States intended to give China a stark choice: join the TPP and accept the restrictions on its state-led practices drafted with that purpose in mind or ignore the TPP and lose the opportunities for increased trade in Asia. See id. at 372-75. After President Trump assumed office in January 2017, however, he withdrew the United States from the TPP. See The United States Officially Withdraws from the Trans-Pacific Partnership, OfFice U.S. Trade RePresentative (Jan. 2017), https://ustr.gov/about-us/policy-offices/press-office/press- 
practical step to further this approach would be for an alliance of countries, consisting of the United States, the European Union, and Japan and others to bring a broad-based case in the WTO dispute settlement system against China challenging its state-led practices.235 The other choice is for China to exit the WTO. This possibility seems unlikely without pressure, but it might be possible to bring pressure on China within the WTO through the U.S.-EUJapan alliance to confront China with the choice to either reform or exit. Both of these approaches have the advantage of squarely raising the issue of what to do about China's state-led economy before the WTO membership. It is beyond the scope of this Article to develop these paths more fully, but that is not this Article's aim. The present aim is to finally dispel the myth created by Clinton that China will dismantle its state-led economy and adopt an open market economy. It is imperative to understand that China will remain a state-led economy so long as the Party is in power. By accepting this sober realization, the United States can deal more effectively in the future with China in the WTO, in bilateral trade negotiations outside of the WTO, and beyond.

releases/2017/january/US-Withdraws-From-TPP [https://perma.cc/5BGZAW53]. The remaining 11 states have indicated that they will form the TPP without the United States, but the United States' absence presents an opportunity for China, which can now join the TPP without any nation having a keen interest in enforcing the provisions directed against China. The United States withdrawal diminishes the TPP, which can also benefit China by allowing it to dominate trade in Asia through its competing free trade agreement, the Regional Comprehensive Economic Partnership (to which the United States was not invited as a member), and perhaps eventually trade throughout the world. For a fuller discussion of these issues, see Daniel C.K. Chow, Ian Sheldon, \& William McGuire, How the United States' Withdrawal from the Trans-Pacific Partnership Benefits China, 4 U. PA. J. L. \& PUB. AFF. 37 (2018).

235 This possibility is proposed in the testimony of Jennifer Hillman before the U.S.-China Economic and Security Review Commission. See Hearing on U.S. Tools to Address Chinese Market Distortions Before the U.S.-China Economic and Review Security Commission, 114th Cong. 2 (2018) (testimony of Jennifer Hillman, Professor from Practice, Georgetown University Law Center),

https://www.uscc.gov/sites/default/files/Hillman\%20Testimony\%20US\%20Chi na $\% 20$ Comm $\% 20 \mathrm{w} \% 20$ Appendix\%20A.pdf [https://perma.cc/T72A-LRDY]. Professor Hillman is a former member of the WTO Appellate Body. Hillman believes that the United States should use the WTO dispute settlement system to challenge China's state-led practices. She disagrees with the USTR that believes that it is not possible or advisable to use the WTO dispute settlement system against China. See 2017 USTR REPORT, supra note 1, at 5. 